\title{
Targeting glioblastoma with oncolytic adenovirus delta 24
}

\author{
Konstantinos I. Tsamis, George A. Alexiou, Athanassios P. Kyritsis \\ Department of Neurology, Medical School, University of Ioannina, 45500 Ioannina, Greece.
}

\section{ONCOLYTIC VIRUSES}

Oncolytic viruses have been introduced in cancer treatment in the last two decades, offering new opportunities and hopes for ultimate therapy. Earlier studies had also tried to take advantage of the antineoplastic activity of natural viral species, but it was genetic engineering that led to the production of modified viral strains selectively infecting and killing neoplastic cells. ${ }^{[1]}$ The two major characteristics of oncolytic viruses are their tropism for malignant cells and their augmented cytotoxicity. The strategies employed to achieve oncotropism involve mainly genetic manipulation of viral vectors in order to either turn them against cells expressing specific surface markers or make them capable to multiply only using the machinery of malignant cells. ${ }^{[2]}$ Despite the capability of specifically targeting neoplastic cells, oncolytic viruses are, usually, not capable to completely demise all malignant cells neither in vivo nor in vitro. ${ }^{[3-5]}$ This inherent limitation of oncolytic viruses is caused principally by restrictions in viral infection due to differential expression of surface viral receptors on different types of malignant cells, ${ }^{[6]}$ by barriers in viral infection in the organism ${ }^{[7,8]}$ as well as by the proliferation of noninfected malignant cells and the development of resistance ${ }^{[9]}$ In this content, significant effort has been invested to increase the viral cytotoxicity. Thus, genetic engineering has been used to modify viral genome in order to produce molecules toxic for cancer cells, in order to increase the cytopathic effect. ${ }^{[10]}$ Furthermore, genes have been employed, causing an augmented immune response against virally infected cells, ${ }^{[11]}$ meanwhile other strategies involve

\begin{tabular}{|l|l|}
\hline \multicolumn{2}{|c|}{ Access this article online } \\
\hline Quick Response Code: & \\
\hline & Website: \\
\hline & www.nnjournal.net \\
& DOI: \\
\hline
\end{tabular}

the modulation of vessel permeability for viruses ${ }^{[8]}$ and degradation of extracellular matrix. ${ }^{[12]}$

\section{DEVELOPMENT OF ONCOLYTIC ADENOVIRUS DELTA 24}

Among tens or even hundreds of different viruses that have been used to produce oncolytic viral vectors with different genetic manipulations, oncolytic adenovirus delta 24 (Ad- $\Delta 24)$ stands out due to its high specificity and toxicity for malignant cells accomplished with simple genetic engineering. Ad- $\Delta 24$ is a mutant replication-competent adenovirus containing a 24 base pair deletion in early region $1 \mathrm{~A}$ gene (E1A), expressing a mutant E1A protein which cannot form complex with the retinoblastoma protein (Rb). ${ }^{[13,14]}$ Thus Ad- $\Delta 24$, unlike wild-type adenovirus, is unable to force the progression of infected normal cells in S phase that is required for its replication. On the other hand, the mutant virus can replicate in cells with disrupted $\mathrm{Rb}$ cell cycle control, like glioma cells. ${ }^{[15]}$ In 2000 , the production of Ad- $\Delta 24$ was described for the first time along with a detailed description of its cytopathic effect on different glioma cell-lines. ${ }^{[13]}$ But despite its potent antiglioma effect, it was obvious even from the first studies that Ad- $\Delta 24$ would need further improvements for optimal therapeutic effect. ${ }^{[16]}$

\section{ADENOVIRUS DELTA 24 DERIVATIVES}

A significant number of modifications have been applied on the initial Ad- $\Delta 24$ system trying to enhance its specific targeting or to augment its oncolytic potency. The most important effort that has been made to enhance glioma targeting was the insertion of an Arg-Gly-Asp peptide (RGD) in the Ad- $\Delta 24$ fiber knob, increasing its affinity with integrins that are highly expressed in gliomas and other tumor cells. ${ }^{[17]}$ Adenovirus infection in general depends on the initial binding to the coxsackievirus and adenovirus receptor (CAR) on the cell surface, followed by a secondary binding to cell surface integrins. ${ }^{[6]}$ Thus, the effect of Ad- $\Delta 24$

Corresponding Author: Dr. Konstantinos I. Tsamis, Department of Neurology, Medical School, University of loannina, 45500 loannina, Greece. E-mail: kłsamis1981@yahoo.gr 
on glioma cells depends upon the expression of CARs on their surface. The vector produced by the insertion of RGD peptide, named Ad- $\Delta 24-R G D$, can overcome this problem since it can directly bind to cell surface integrins. ${ }^{[17]}$

Furthermore, a number of studies have focused on augmenting the oncolytic potency of Ad- $\Delta 24$. Genetic manipulations were used in order to produce vectors expressing p53, ${ }^{[18]}$ TRAIL and Arresten, ${ }^{[19]}$ cytosine deaminase ${ }^{[20]}$ and the tissue inhibitor of matrix metalloproteinase-3 ${ }^{[21]}$ All these Ad- $\Delta 24$ derivatives are claimed to be superior to the initial vector but their efficacy awaits further confirmation.

\section{COMBINATION TREATMENTS}

Other studies have tried to improve the therapeutic effect of Ad- $\Delta 24$ and its derivatives through combining treatments with apoptotic and chemotherapeutic agents, as well as radiation. Treatment to glioma with Ad- $\Delta 24$ or its derivatives has been observed to enhance when combined with TRAIL ${ }^{[16]}$ adenovirus expressing p53, ${ }^{[22]}$ temozolomide, ${ }^{[23]}$ radiation ${ }^{[24]}$ and topoisomerase I inhibitor irinotecan. ${ }^{[25]}$ Autophagic induced cell death and induction of apoptosis are well-characterized results of Ad- $\Delta 24$ infection giving the erratum for combination treatments. ${ }^{[26]}$

\section{ANTITUMOR IMMUNE RESPONSE}

Another important aspect of oncolytic virotherapy is the induction of augmented antitumor immune response. ${ }^{[27,28]} \mathrm{Ad}-\Delta 24-\mathrm{RGD}$ has been shown to induce antiglioma immunity and to enhance the presentation of tumor-associated antigens to immune cells. ${ }^{[29]}$ These findings provide the base for further genetic manipulation of Ad- $\Delta 24$ in order to drive the production of immunostimulatory factors (like granulocyte-macrophage colony stimulating factor) that can possibly mediate more robust therapeutic effects. ${ }^{[30]}$

\section{CLINICAL TRIALS}

Ad- $\Delta 24$ and its derivatives have been tested in clinical trials in patients with solid tumors, and more studies are in progress. The first results show that these agents are safe, but their antitumor efficacy remains modest. ${ }^{[30,31]}$ Ad- $\Delta 24-R G d$ is also being tested in a clinical trial in patients with malignant gliomas and the results are still pending.

\section{CONCLUSION}

Ad- $\Delta 24$ is a promising agent for glioblastoma treatment. The initial vector developed 14 years ago providing a platform for further genetic modifications and combination treatments. Since the first clinical trials have assured its safety, it is important for the future research to seek for enhancements in its genome and combining agents that could refine its effect.

\section{REFERENCES}

1. Kelly E, Russell SJ. History of oncolytic viruses: genesis to genetic engineering. Mol Ther 2007;15:651-9.

2. Vacchelli E, Eggermont A, Sautès-Fridman C, Galon J, Zitvogel L, Kroemer G, Galluzzi L. Trial watch: oncolytic viruses for cancer therapy. Oncoimmunology 2013;2:e24612.

3. Li ZY, Ni S, Yang X, Kiviat N, Lieber A. Xenograft models for liver metastasis: relationship between tumor morphology and adenovirus vector transduction. Mol Ther 2004;9:650-7.

4. Shayakhmetov DM, Li ZY, Ni S, Lieber A. Targeting of adenovirus vectors to tumor cells does not enable efficient transduction of breast cancer metastases. Cancer Res 2002;62:1063-8.

5. Ram Z, Culver KW, Oshiro EM, Viola JJ, DeVroom HL, Otto E, Long Z, Chiang Y, McGarrity GJ, Muul LM, Katz D, Blaese RM, Oldfield EH. Therapy of malignant brain tumors by intratumoral implantation of retroviral vector-producing cells. Nat Med 1997;3:1354-61.

6. Sharma A, Li X, Bangari DS, Mittal SK. Adenovirus receptors and their implications in gene delivery. Virus Res 2009;143:184-94.

7. Cairns R, Papandreou I, Denko N. Overcoming physiologic barriers to cancer treatment by molecularly targeting the tumor microenvironment. Mol Cancer Res 2006;4:61-70.

8. Fang J, Nakamura H, Maeda H. The EPR effect: unique features of tumor blood vessels for drug delivery, factors involved, and limitations and augmentation of the effect. Adv Drug Deliv Rev 2011;63:136-51.

9. Ottolino-Perry K, Diallo JS, Lichty BD, Bell JC, McCart JA. Intelligent design: combination therapy with oncolytic viruses. Mol Ther 2010;18:251-63.

10. Morrison J, Briggs SS, Green N, Fisher K, Subr V, Ulbrich K, Kehoe S, Seymour LW. Virotherapy of ovarian cancer with polymer-cloaked adenovirus retargeted to the epidermal growth factor receptor. Mol Ther 2008;16:244-51.

11. Galluzzi L, Senovilla L, Zitvogel L, Kroemer G. The secretally: immunostimulation by anticancer drugs. Nat Rev Drug Discov 2012;11:215-33.

12. Guedan S, Rojas JJ, Gros A, Mercade E, Cascallo M, Alemany R Hyaluronidase expression by an oncolytic adenovirus enhances its intratumoral spread and suppresses tumor growth. Mol Ther 2010;18:1275-83.

13. Fueyo J, Gomez-Manzano C, Alemany R, Lee PS, McDonnell TJ, Mitlianga P, Shi YX, Levin VA, Yung WK, Kyritsis AP. A mutant oncolytic adenovirus targeting the $\mathrm{Rb}$ pathway produces anti-glioma effect in vivo. Oncogene 2000;19:2-12.

14. Whyte P, Williamson NM, Harlow E. Cellular targets for transformation by the adenovirus E1A proteins. Cell 1989;56:67-75.

15. Kyritsis AP, Sioka C, Rao JS. Viruses, gene therapy and stem cells for the treatment of human glioma. Cancer Gene Ther 2009;16:741-52.

16. Tsamis KI, Alexiou GA, Vartholomatos E, Kyritsis AP. Combination treatment for glioblastoma cells with tumor necrosis factor-related apoptosis-inducing ligand and oncolytic adenovirus delta-24. Cancer Invest 2013;31:630-8.

17. Fueyo J, Alemany R, Gomez-Manzano C, Fuller GN, Khan A, Conrad CA, Liu TJ, Jiang H, Lemoine MG, Suzuki K, Sawaya R, Curiel DT, Yung WK, Lang FF. Preclinical characterization of the antiglioma activity of a tropism-enhanced adenovirus targeted to the retinoblastoma pathway. J Natl Cancer Inst 2003;95:652-60.

18. Geoerger B, Vassal G, Opolon P, Dirven CM, Morizet J, Laudani L, Grill J, Giaccone G, Vandertop WP, Gerritsen WR, van Beusechem VW. Oncolytic activity of p53-expressing conditionally 
replicative adenovirus AdDelta24-p53 against human malignant glioma. Cancer Res 2004;64:5753-9.

19. Li X, Mao $Q$, Wang $D$, Zhang W, Xia H. A fiber chimeric CRAd vector Ad5/11-D24 double-armed with TRAIL and arresten for enhanced glioblastoma therapy. Hum Gene Ther 2012;23:589-96.

20. Conrad C, Miller CR, Ji Y, Gomez-Manzano C, Bharara S, McMurray JS, Lang FF, Wong F, Sawaya R, Yung WK, Fueyo J. Delta24-hyCD adenovirus suppresses glioma growth in vivo by combining oncolysis and chemosensitization. Cancer Gene Ther 2005;12:284-94.

21. Lamfers ML, Gianni D, Tung $\mathrm{CH}$, Idema S, Schagen $\mathrm{FH}$, Carette JE, Quax PH, Van Beusechem VW, Vandertop WP, Dirven CM, Chiocca EA, Gerritsen WR. Tissue inhibitor of metalloproteinase-3 expression from an oncolytic adenovirus inhibits matrix metalloproteinase activity in vivo without affecting antitumor efficacy in malignant glioma. Cancer Res 2005;65:9398-405.

22. Mitlianga PG, Sioka C, Vartholomatos G, Goussia A, Polyzoidis K, Rao JS, Kyritsis AP. p53 enhances the Delta-24 conditionally replicative adenovirus anti-glioma effect. Oncol Rep 2006;15:149-53.

23. Alonso MM, Gomez-Manzano C, Jiang H, Bekele NB, Piao Y, Yung WK, Alemany R, Fueyo J. Combination of the oncolytic adenovirus ICOVIR-5 with chemotherapy provides enhanced anti-glioma effect in vivo. Cancer Gene Ther 2007;14:756-61.

24. Idema S, Lamfers ML, van Beusechem VW, Noske DP, Heukelom S, Moeniralm S, Gerritsen WR, Vandertop WP, Dirven CM. AdDelta24 and the p53-expressing variant AdDelta24-p53 achieve potent anti-tumor activity in glioma when combined with radiotherapy. J Gene Med 2007;9:1046-56

25. Gomez-Manzano C, Alonso MM, Yung WK, McCormick F, Curiel DT, Lang FF, Jiang H, Bekele BN, Zhou X, Alemany R, Fueyo J. Delta-24 increases the expression and activity of topoisomerase I and enhances the antiglioma effect of irinotecan. Clin Cancer Res 2006;12:556-62.
26. Jiang H, White EJ, Ríos-Vicil CI, Xu J, Gomez-Manzano C, Fueyo J. Human adenovirus type 5 induces cell lysis through autophagy and autophagy-triggered caspase activity. $J$ Virol 2011;85:4720-9.

27. Chinnery F, King CA, Elliott T, Bateman AR, James E. Viral antigen mediated NKp46 activation of NK cells results in tumor rejection via NK-DC crosstalk. Oncoimmunology 2012;1:874-83.

28. Russell SJ, Peng KW, Bell JC. Oncolytic virotherapy. Nat Biotechnol 2012;30:658-70.

29. Jiang H, Clise-Dwyer K, Ruisaard KE, Fan X, Tian W, Gumin J, Lamfers ML, Kleijn A, Lang FF, Yung WK, Vence LM, Gomez-Manzano C, Fueyo J. Delta-24-RGD oncolytic adenovirus elicits anti-glioma immunity in an immunocompetent mouse model. PLoS One 2014;9:e97407.

30. Pesonen S, Diaconu I, Cerullo V, Escutenaire S, Raki M, Kangasniemi L, Nokisalmi P, Dotti G, Guse K, Laasonen L, Partanen K, Karli E, Haavisto E, Oksanen M, Karioja-Kallio A, Hannuksela P, Holm SL, Kauppinen S, Joensuu T, Kanerva A, Hemminki A. Integrin targeted oncolytic adenoviruses Ad5-D24-RGD and Ad5-RGD-D24-GMCSF for treatment of patients with advanced chemotherapy refractory solid tumors. Int $J$ Cancer 2012;130:1937-47.

31. Pol J, Bloy N, Obrist F, Eggermont A, Galon J, Cremer I, Erbs P, Limacher JM, Preville X, Zitvogel L, Kroemer G, Galluzzi L. Trial Watch: oncolytic viruses for cancer therapy. Oncoimmunology 2014;3:e28694.

Cite this article as: Tsamis KI, Alexiou GA, Kyritsis AP. Targeting glioblastoma with oncolytic adenovirus delta 24 . Neuroimmunol Neuroinflammation 2015;2(1):1-3

Source of Support: Nil. Conflict of Interest: No.

Received: 28-08-2014; Accepted: 26-09-2014 